\title{
PENGARUH PEMANFAATAN PUPUK BOKASI FESES SAPI TERHADAP PRODUKSI SORGUM VARIETAS KAWALI
}

\author{
Edward Tacoh, A. Rumambi *, W. B. Kaunang \\ Fakultas Peternakan Universitas Sam Ratulangi Manado, 95115
}

\begin{abstract}
ABSTRAK
Sorgum (Sorgum bicolor L.Moench), merupakan salah satu jenis rumput-rumputan yang dapat di jadikan sumber hijauan cukup potensial untuk dikembangkan di Indonesia karena sorgum memiliki keunggulan tahan terhadap kekeringan dibandingkan jenis serealia lainnya, mampu beradaptasi pada daerah yang luas, dapat digunakan sebagai bahan pangan dan pakan ternak alternatif. Dilihat dari kandungan nutrisi, tanaman sorgum lebih tinggi dari pada beras dan jagung terutama dari kandungan protein. Penelitian ini bertujuan untuk mengetahui dan memperoleh data tentang pengaruh pemberian pupuk bokasi feses sapi yang menggunakan EM4 terhadap produksi tanaman sorgum. Penelitian ini telah dilaksanakan di desa Wusa Kecamatan Talawaan Minahasa Utara. Rancangan yang digunakan adalah Rancangan Acak Lengkap (RAL), terdiri dari 4 Perlakuan dan 5 Ulangan sehingga diperoleh 20 satuan percobaan. Perlakuan terdiri dari $\mathrm{P} 0=$ Tanpa bokasi, $\mathrm{P}=$ Bokasi $4 \mathrm{~kg}, \mathrm{P} 2=$ Bokasi $8 \mathrm{~kg}, \mathrm{P} 3=$ Bokasi $12 \mathrm{~kg}$. Variabel yang diukur yaitu berat malai, panjang malai dan berat biji. Hasil analisis menunjukan bahwa perlakuan dengan 12 $\mathrm{kg} /$ petak memberikan pengaruh sangat nyata $(\mathrm{P}<0,01)$ terhadap panjang malai, berat malai dan berat biji dibanding dengan kontrol tanpa perlakuan dan perlakuan lannya yaitu 8 dan $4 \mathrm{~kg} /$ petak. Berdasarkan hasil penelitian dapat disimpulkan bahwa pemberian bokasi
\end{abstract}

*Korespondensi (corresponding Author)

Email: agnitjerumambi@ymail.com dengan takaran $12 \mathrm{~kg} /$ petak meningkatkan produksi tanaman yang diukur melalui panjang malai, berat malai dan berat biji.

Kata kunci: Pupuk, sorgum, feses sapi, EM4, produksi

ABSTRACT
EFFECT OF THE USE OF
FECES TOKASHI
COW SORGHUM
FERTILIZER TO
VARIETY KAWALI PRODUCTION.
Sorghum (Sorghum bicolor L.Moench), is
one type of grass that can be a source of
forage potential to be developed in
Indonesia because sorghum has the
advantage of a drought resistant than other
types of cereal crops, able to adapt to a
wide area, sorghum used as food and
animal feed alternatives. Seen from the
content of nutrients, sorghum is higher
than rice and maize especially of protein.
This research aims to identify and obtain
data about the effect of cow feces organic
fertilizer that using EM4 for sorghum
production. This research
implemented in Wusa village at districts
Talawaan. The design used was
completely randomized design (CRD),
which consists of 4 treatments and 5
replications to obtain 20 units of trial. The
treatment consists of P0= without
fertilization, P1= 4 kg of fertilization, P2=
8 kg of fertilization, P3= 12 kg of
fertilization, the measured variables are
panicle weight, panicle length and the
weight of seeds. Result of the analysis


showed that treatment with $12 \mathrm{~kg} / \mathrm{plot}$ provides highly significant effect $(\mathrm{P}<0.01)$ of the panicle length, panicle weight and the weight of seeds compared with other treatments, ie 8 and $4 \mathrm{~kg} / \mathrm{plot}$. Based on the results of research concluded that giving bokashi with a dose of $12 \mathrm{~kg} / \mathrm{plot}$ improve crop production as measured through panicle length, panicle weight and the weight of seeds.

Keywords: Fertilizer, sorghum, cow feces, EM4, Production

\section{PENDAHULUAN}

Hijauan pakan merupakan salah satu jenis rumput-rumputan yang sangat penting bagi ternak, terutama ternak ruminansia dimana hijauan merupakan sumber utama dan sangat besar peranannya bagi ternak baik untuk hidup pokok, produksi maupun reproduksi. Meningkatnya jumlah populasi ternak perlu diimbangi dengan ketersediaan hijauan pakan berkualitas dan berkesinambungan.

\section{Sorgum (Sorghum bicolor L.} Moench), merupakan salah satu jenis rumput-rumputan berkualitas baik dan berproduksi tinggi dapat di jadikan sumber pakan potensial untuk dikembangkan di Indonesia. Sorgum memiliki beberapa keunggulan seperti dapat tumbuh di lahan kering, resiko kegagalan relatif kecil, kandungan nutrisi cukup tinggi, relatif lebih tahan hama penyakit dibandingkan tanaman pangan lainnya serta pembiayaan usahatani relatif murah. Dalam pemanfaatannya sorgum memiliki manfaat yang cukup banyak, hal ini dikarenakan bagian dari tanaman sorgum seperti batang, daun, dan biji dapat dimanfaatkan baik untuk memenuhi kebutuhan pangan dan pakan ternak.

Biji sorgum dapat digunakan sebagai pengganti jagung dalam ransum, karena dari segi kualitas hampir sama dengan jagung, sehingga pengembangan sorgum dalam bidang peternakan ditunjukkan untuk menggantikan sebagian atau seluruh peranan jagung dalam ransum ternak. Penggunaan biji sorgum dalam ransum pakan bersifat suplemen atau pengganti jagung, sedangkan untuk daun dan batang segar dapat dimanfaatkan sebagai pakan ruminansia. Kandungan nutrisi biji sorgum berdasarkan 100\% bahan kering berupa Protein 10,26; Serat kasar 2,72; Lemak 2,70; Ca 0,90; dan P 0,38 (Rumambi, 2013), sedangkan untuk komposisi daun sorgum setara dengan rumput gajah dan pucuk tebu terutama dari segi protein yang maisng-masing adalah : $7,8 \%, 6,0 \%$ dan $5,0 \%$

Di Indonesia produksi sorgum masih rendah, hal ini antara lain disebabkan oleh rendahnya kesuburan tanah, sehingga perlu upaya penambahan unsur hara melalui pemupukan. Pupuk organik bokasi memiliki keunggulan dan manfaat yaitu, meningkatkan populasi, 
keragaman dan aktivitas mikroorganisme yang menguntungkan dan menekan perkembangan patogen yang ada dalam tanah. Bokasi feses sapi merupakan salah satu alternatif dalam penerapan teknologi pertanian organik yang berwawasan lingkungan dan berkelanjutan, selain itu bokasi feses sapi dapat memberikan manfaat dalam menyediakan unsur hara makro dan mikro bagi tanaman, dapat menggemburkan tanah, memperbaiki struktur tanah, sehingga memudahkan pertumbuhan akar tanaman dalam menyerap air dan unsur hara. Komposisi unsur hara yang terkandung dalam pupuk bokasi feses sapi menurut (Hartatik dan Widowati, 2010) yaitu: $\mathrm{N}(0,7-1,3 \%), \mathrm{P}_{2} \mathrm{O}_{5}$ $(1,5-2,0 \%), \mathrm{K}_{2} \mathrm{O}_{5}(0,5-0,8 \%), \mathrm{C}$ organic $(10,0-11,0 \%, \operatorname{MgO}(0,5-0,7 \%)$ dan $\mathrm{C} / \mathrm{N}$ ratio $(14,0-18,0)$. Bokashi merupakan hasil fermentasi bahan organik berupa limbah pertanian berupa pupuk kandang, jerami, sekam dan serbuk gergaji dengan menggunakan EM-4 (Atikah, 2013; Gao et al, 2012). Berdasarkan latar belakang diatas telah dilakukan penelitian untuk mengetahui dan memperoleh data tentang pengaruh pemberian pupuk bokasi feses sapi untuk produksi tanaman sorgum.

\section{MATERI DAN METODE PENELITIAN}

\section{Tempat dan Waktu Penelitian}

Penelitian ini telah dilakukan di lahan milik, Dr. Ir. Agnitje Rumambi, Msi di desa Wusa Kecamatan Talawaan Minahasa Utara. Penelitian ini dilaksanakan selama 4 bulan.

\section{Materi Penelitian}

Bahan yang digunakan dalam penelitin ini terdiri dari benih sorgum variates kawali, feses sapi, EM4, gula putih, air, serbuk gergaji, dedak halus dan tanah sebagai media tanam, sedangkan alat yang digunakan berupa cangkul, meter, timbangan, parang, kamera, bambu, paku, kertas HVS warna, tali, plastik, gunting, gelas ukur, sekop, ember, terpal, termometer dan alat tulis menulis.

\section{Pembuatan Bokasi Feses Sapi}

Persiapan bahan berupa larutan EM4 + gula + air dicampur merata. Selanjutnya penyiapan bahan-bahan pengisi seperti feses sapi, dedak halus, sekam padi, serbuk gergaji. Semua bahan pengisi di campur secara bertahap, bahan olahan ditutup menggunakan karung goni. Pengecekan suhu dilakukan setiap 5-6 jam, apabila terjadi peningkatan suhu pada bahan olahan perlu dilakukan pembongkaran dengan cara membolakbalikan bahan tersebut agar terjadi penurunan suhu kemudian ditutup kembali. Bokashi dapat digunakan apabila 
telah memiliki ciri berwarna coklat kehitaman, tekstur lembut, gembur, tidak panas, dan tidak berbau busuk.

\section{Persiapan lahan}

Pembersihan lahan dilakukan melalui pembersihan tanah dengan cara pembajakkan atau pembongkaran tanah kemudian dilakukan penyisiran agar bersih dari sisa-sisa tanaman dan rumput liar dilanjutkan dengan pembuatan petak sebanyak 20 petak dengan ukuran $2 \times 3$ meter. Jarak antar petak adalah $50 \times 75$ $\mathrm{cm}$. Tanah yang telah dibuat petak-petak tadi dibiarkan selama 1 minggu untuk membiarkan kesempatan bagi rumput liar tumbuh kemudian dicangkul kembali. Dilanjutkan dengan pemberian pupuk sesuai perlakuan pada tiap-tiap petak. Adapun perlakuan yang digunakan dalam penelitian ini adalah level pemberian pupuk bogashi yang terdiri dari:

$$
\begin{aligned}
& \text { P0 }=\text { Tanpa pemupukan } \\
& \text { P1 }=\text { Pupuk bokasi } 4 \mathrm{~kg} \\
& \text { P2 }=\text { Pupuk bokasi } 8 \mathrm{~kg} \\
& \text { P3 }=\text { Pupuk bokasi } 12 \mathrm{~kg}
\end{aligned}
$$

\section{Penanaman}

Penanaman dilakukan dengan cara tunggak, dimana setiap lubang ditanami 23 butir, setelah tanaman berumur 1 minggu dilakukan penjarangan tanaman dengan meninggalkan satu tanaman per lubang. Setiap petak ditanami 18 tanaman sehingga keseluruhan petak berjumlah 360 tanaman.

Pemeliharaan tanaman meliputi penyiangan dilakukan apabila muncul tanaman pengganggu dalam petak percobaan. Untuk membasmi hama dilakukan penyemprotan menggunakan furadan dan sefin pada tanaman yang terserang hama.

\section{Peubah yang diukur}

Peubah yang diukur dalam penelitian ini adalah produksi sorgum varieatas kawali yang terdiri dari panjang malai $(\mathrm{cm})$, berat malai $(\mathrm{g})$ dan berat biji (g). Pengambilan data dilakukan selama 70 hari untuk panjang malai sedangkan pada umur 105 hari untuk pengambilan berat malai dan berat biji.

\section{Analisis Data}

Data yang diperoleh dianalisis menggunakan analisis varian dengan pola rancangan Rancangan Acak Lengkap (RAL) yang terdiri dari 4 perlakuan dan 5 ulangan. Apabila terjadi perbedaan rataan dilanjutkan dengan uji BNJ. Prosedur analisa data menurut petunjuk Steel dan Torrie (1991). 


\section{HASIL DAN PEMBAHASAN}

\section{Perlakuan Pemupukan Bokasi Feses Sapi Terhadap Panjang Malai $(\mathrm{Cm})$}

Rataan pengaruh perlakuan terhadap panjang malai dapat dilihat pada Tabel 1. terhadap panjang malai. Hasil analisis menunjukkan bahwa perlakuan memberikan pengaruh yang berbeda sangat nyata $(\mathrm{P}<0,01)$ terhadap panjang malai. Hasil uji BNJ menunjukkan bahwa pemupukan bokasi feses sapi sebanyak 12 $\mathrm{kg} /$ petak sangat nyata $(\mathrm{P}<0,01)$ menghasilkan malai lebih panjang yaitu 28,31 cm dibandingkan dengan kontrol tanpa pemberian pupuk bokasi feses sapi yaitu $25,14 \mathrm{~cm}$, dengan nilai rata-rata yaitu $26,72 \mathrm{~cm}$, kemudian diikuti oleh P2 $(26,91$ $\mathrm{cm})$, P1 $(26,11 \mathrm{~cm})$. Hasil penelitian ini lebih tinggi dari penelitian Tarigan et al. (2015) yang menggunakan pupuk kimia yaitu urea 300 g/plot, TSP 200 g/plot dan $\mathrm{KCl} 180 \mathrm{~g} /$ plot pada tanaman sorgum menghasilkan panjang malai berkisar antara 18,63 cm sampai dengan 32,93 cm dengan nilai rata-rata $25,04 \mathrm{~cm}$. Penelitian ini juga lebih tinggi dari penelitian Basri et al. (2015), yang menggunakan pupuk kandang feses kambing ditambahkan NPK memperoleh hasil yaitu $16,63 \mathrm{~cm}$, pemberian pupuk kandang feses dengan NPK memperoleh hasil yang lebih rendah yaitu $10,21 \mathrm{~cm}$. Panjang malai tertinggi pada perlakuan P3 disebabkan karena peningkatan pemberian bokasi feses sapi. Diketahui bahwa pupuk bokasi feses sapi memiliki keunggulan yaitu mempunyai kadar serat yang tinggi seperti selulosa, menyediakan unsur hara makro dan mikro lengkap bagi tanaman serta memperbaiki daya serap air pada tanah (Dahlan dan Khairudin, 2007). Pupuk kandang (sapi) mempunyai kandungan hara yang lengkap (Lingga, 2002), sehingga dapat meningkatkan dan memperbaiki sifat fisik, kimia dan biologi tanah (Sarif, 1985). Panjang malai dapat dibagi menjadi 3 kelompok berdasarkan ukurannya yaitu malai pendek berukuran kurang dari 20 $\mathrm{cm}$, malai sedang berukuran $20-30 \mathrm{~cm}$,

Tabel 1. Rataan panjang malai (PM), berat malai (BM) dan berat biji (BB) sorgum varietas kawali yang diberi pupuk bokasi feses sapi

\begin{tabular}{lcccc}
\hline Variabel & P0 & P1 & P2 & P3 \\
\hline PM $(\mathrm{cm})$ & $25,14 \pm 1,04^{\mathrm{a}}$ & $26,11 \pm 0,93^{\mathrm{ab}}$ & $26,91 \pm 1,14^{\mathrm{b}}$ & $28,31 \pm 0,57 \mathrm{~b}$ \\
$\mathrm{BM}(\mathrm{g})$ & $282,60 \pm 20,78^{\mathrm{a}}$ & $282,60 \pm 36,473^{\mathrm{a}}$ & $358,00 \pm 23,02^{\mathrm{b}}$ & $377,80 \pm 22,02^{\mathrm{b}}$ \\
$\mathrm{BB}(\mathrm{g})$ & $31,20 \pm 1,79^{\mathrm{a}}$ & $34,00 \pm 1,58^{\mathrm{ab}}$ & $39,40 \pm 1,52^{\mathrm{b}}$ & $46,00 \pm 4,64^{\mathrm{c}}$ \\
\hline
\end{tabular}

Keterangan: Superskrip pada baris yang sama menunjukkan perbedaan nyata $(\mathrm{P}<0,01)$ 
dan malai panjang berukuran lebih dari 30 cm (Marliah dan Jumini, 2010). Panjang malai dalam penelitian ini termasuk dalam kelompok malai sedang.

\section{Perlakuan Pemupukan Bokasi Feses Sapi Terhadap Berat Malai}

Rataan pengaruh perlakuan terhadap berat malai dapat dilihat pada Tabel 1. Nilai rataan pada perlakuan P3 menunjukkan nilai tertinggi yaitu 377,80 g dibandingkan dengan kontrol tanpa pemupukan yaitu 282,60 g, diikuti dengan perlakuan P2 dan P1 yang masing-masing adalah $358,00 \mathrm{~g}$ dan $282,60 \mathrm{~g}$. Hasil uji BNJ menunjukkan bahwa perlakuan P3 menunjukan perbedaan yang sangat nyata $(\mathrm{P}<0,01)$ menghasilkan berat malai yang lebih berat. Pengaruh perlakuan antara P3 dan P1, P3 dan P2 memberikan pengaruh berbeda tidak nyata $(\mathrm{P}<0,05)$. Berat malai terberat terdapat pada perlakuan P3. Hal ini diduga disebabkan karena kandungan unsur hara bokasi feses sapi tersedia dan dapat diserap tanaman. Unsur hara diserap akar ditentukan oleh semua faktor yang mempengaruhi ketersediaan unsur hara sampai hara berada dipermukaan akar, sehingga mempengaruhi pertumbuhan, perkembangan dan hasil tanaman (Agustina, 1990). Pupuk bokasi feses sapi mengandung bahan organik yang berperan penting memperbaiki sifat fisika, kimia, dan biologi tanah dan memiliki sifat yang alami dan tidak merusak tanah. Syekhfani, (2000) menyatakan bahwa pupuk kandang berfungsi untuk meningkatkan daya menahan air, aktivitas mikrobiologi tanah, nilai kapasitas tukar kation dan memperbaiki struktur tanah.

Bokasi feses sapi dapat dianggap sebagai pupuk yang lengkap, karena selain menghasilkan hara yang tersedia, juga meningkatkan aktvitas mikroorganisme di dalam tanah. Adanya EM4 sebagai elemen bokasi sangat bermanfaat, mengingat cara kerja EM4 dalam tanah secara sinergis dapat meningkatkan kesuburan tanah, baik fisik, kimia, dan biologis sehingga dapat meningkatkan pertumbuhan dan produktivitas tanah dan tanaman (Sutedjo, 1994).

\section{Perlakuan Pemupukan Bokasi Feses Sapi Terhadap Berat Biji}

Rataan pengaruh perlakuan terhadap berat biji dapat dilihat pada Tabel 1. Hasil analisis keragaman menunjukkan bahwa perlakuan memberikan pengaruh yang berbeda sangat nyata $(\mathrm{P}<0,01)$ terhadap berat biji tanaman sorgum. Pada hasil uji BNJ menunjukkan bahwa pemupukan bokasi feses sapi sebanyak $12 \mathrm{~kg} /$ petak (P3) sangat nyata $(\mathrm{P}<0,01)$ menghasilkan biji yang berat yaitu 46,00 g dibandingkan kontrol P0, P1 dan P2 yang masingmasing yaitu $31,20 \mathrm{~g}, 34,00 \mathrm{~g}$ dan $39,40 \mathrm{~g}$. 
Hal ini terjadi karena pupuk bokasi feses sapi memberikan respon pertambahan berat biji berbanding lurus dengan kenaikan tingkat pemberian pupuk bokasi feses sapi.

Adanya perbedaan berat biji sorgum dengan bertambahnya tingkat pemupukan bokasi feses sapi, hal ini disebabkan oleh perbedaan kandungan hara didalam tanah sebagai akibat kontribusi pemberian pupuk bokasi feses sapi dapat mendukung kesuburan tanah dan menyediakan unsur nitrogen, fosfor, kalium, kalsium dan belerang serta unsur mikro seperti besi, seng, boron, kobal dan molybdenum (Nasahi, 2010). Pendapat yang sama (Rosmarkam dan Yuwono, 2002), menyatakan bahwa pupuk kandang dapat menyediakan unsur hara makro $(\mathrm{N}, \mathrm{P}, \mathrm{K})$ dan mikro ( $\mathrm{Ca}, \mathrm{Mg}, \mathrm{S}, \mathrm{Na}, \mathrm{Fe}, \mathrm{Cu}, \mathrm{Mo}$ ). Marliah dan Jumini (2010) menyatakan bahwa fosfor berfungsi sebagai bahan mentah untuk pembentukan sejumlah protein tertentu, membantu asimilasi dan pernafasan, serta mempercepat pembungaan, pemasakan biji, dan buah. Ketersediaan hara yang berbeda ini memberikan respon berbeda terhadap berat biji sorgum. Biji sorgum adalah hasil tanaman dimana jumlah dan beratnya merupakan ukuran produksi, semakin besar jumlah berat biji yang dihasilkan maka semakin besar produksi yang diperoleh.
Unsur nitrogen merupakan salah satu unsur yang dibutuhkan untuk pengisian biji, selain itu nitrogen dapat meningkatkan laju fotosintesis sehingga fotosintat yang dihasilakn dari proses tersebut lebih banyak untuk ditranslokasikan pada pengisian biji. Hal ini juga didukung oleh pernyataan Musa dan Syamsudin (1978), dimana hasil biji setiap tanaman selain dipengaruhi oleh genotipe, juga dipengaruhi oleh budidaya dan keadaan lingkungan tumbuh. sehingga dapat meningkatkan dan memperbaiki sifat fisik, kimia dan biologi tanah (Sarif, 1985).

\section{KESIMPULAN}

Berdasarkan hasil penelitian dapat disimpulkan bahwa pemberian pupuk bokasi feses sapi sampai dengan 12 $\mathrm{kg} /$ pertak memberikan pengaruh yang terbaik terhadap panjang malai, berat malai dan berat biji tanaman sorgum.

\section{DAFTAR PUSTAKA}

Agustina. L. 1990. Dasar Nutrisi Tanaman. Rhineka Cipta. Jakarta

Atikah, T.A. 2013. Pertumbuhan dan hasil tanaman terung ungu varietas Yumi F1 dengan pemberian berbagai bahan organik dan lama inkubasi pada tanah berpasir. Anterior Jurnal 12(2): 6-12. 
Basri. H., F. Pusfita, S.I. Sautra. 2015. Pemberian kombinasi pupuk kandang dengan NPK pada pertumbuhan tanaman sorgum (sorghum bicolor (L.)Moench). Jurnal Online Mahasiswa Faperta, Unri.Vol 2(1): 1-14. Diakses Tanggal 12 Februari 2016.

Dahlan, F.H dan Khairudin. 2007. Pengaruh penggunaan pemberian pupuk bokashi kotoran sapi terhadap pertumbuhan dan produksi tanaman jagung. Jurnal agribisnis. Vol. 3(1):

Gao M., J. Li and X. Zhang. 2012. Responses of soil fauna structure and leaf litter decomposition to effective microorganism treatments in da hinggan mountains. Chinese Geographical Science 22(6):647658.

Hartatik, W. dan L.R. Widowati, 2010. Pupuk Kandang. Diakses tanggal 31 Januari 2016.

Lingga, P. 2002. Petunjuk Penggunaan Pupuk. Penebar Swadaya, Jakarta

Marliah. A dan Jumini. 2010. Respons bibit jarak pagar pada berbagai komposisi media tanam dan konsentrasi pupuk daun novelgro. J. Floratek 5: 54-64.

Musa, B. A. S dan E. Syamsudin. 1978. Pengantar Pemuliaan Tanaman. IPB. Bogor

Nasahi, Ceppy M. S. (2010). Peran Mikrobia dalam Pertanian Organik.
Fakultas Pertanian Universitas Padjadjaran Bandung.

Rumambi, A. 2013. Karakteristik pertumbuhan sorgum dengan pemupukan urea berbeda sebagai sumber nitrogen. Jurnal Agrosistem Vol. 10 (1) : 1-12

Rosmarkam, A. dan N.W. Yuwono. 2002. Ilmu Kesuburan Tanah. Kanisius.Yogyakarta.

Sarif, E. S. 1985. Pupuk dan Cara Pemupukan. Bhatara Karya Aksara. Jakarta.

Steel, R.G.D. dan J. H. Torrie. 1991. Prinsip dan Prosedur Statistika Suatu Pendekatan Biometrik.Edisi kedua. Gramedia Pustaka Utama. Jakarta

Sutedjo, M. M., 1994. Pupuk dan Cara Pemupukan. Rhineka Cipta, Jakarta.

Syekhfani. 2000. Arti Penting Bahan Organik Bagi Kesuburan Tanah. Kongres I dan Semiloka Nasional MAPORINA, Malang

Tarigan. J. A., E. Zuhry dan Nurbaiti. 2015. Uji daya hasil beberapa genotype sorgum manos (sorgum bicolor (L.) Moench) koleksi batan. Jurnal Online Mahasiswa Faperta, Unri.Vol 2(1): 1-15. Diakses Tanggal 12 Februari 2016 